\title{
Doğal Afet Nedeniyle Post Travmatik Stres Bozukluğu Yaşayan Bir Çocuk Olguda Hemşirelik Bakımının Planlanmasında Fonksiyonel Sağlık Örüntüleri Modeli'nin Kullanılması
}

\section{Maintaing nursing care of children who suffer from Post Traumatic Stress Disorder because of natural disaster through Functional Health Patterns}

\author{
Sevil İNAL ${ }^{\mathrm{a}}$, Leyla ERDİM ${ }^{\mathrm{b}}$
}

\begin{abstract}
Özet Deprem, kasırga, hortum, yangın veya sel gibi bir felaket yetişkinler için olduğu gibi çocuklar için de korkutucudur. Çeşitli faktörler çocuğun afete karşı tepkisini etkiler. Çocuk hemşiresi Post Travmatik Stres Bozukluğu (PTSB) yaşayan çocuğun bakımında önemli rol oynar. Doğal afetten etkilenen çocuğun hemşirelik bakımı PTSB önlenmesine ya da azaltılmasına yardım eder. Bu makalede doğal afet nedeniyle PTSB yaşayan çocuk ve ailesinin hemşirelik bakımı, Marjorie Gordon'un Fonksiyonel Sağlık Örüntüleri Modeline göre incelendi. Anahtar Sözcükler: Post travmatik stres bozukluğu, doğal afet, çocuk hemşireliği, Gordon'un Sağlık Örüntüleri Modeli, olgu analizi.
\end{abstract}

\begin{abstract}
A catastrophe such as an earthquake, hurricane, tornado, fire or flood acts is frightening to children and adults alike. Several factors affect a child's response to a disaster. Pediatric nurses play a significant role care of children who suffer from Post Traumatic Stress Disoreder (PTSD). Professional nursing care of children affected by a disaster can help prevent or minimize PTSD. In this manuscript will be discussed care of child and family who develop Post Travmatik Stress Disorder related to natural disasters(earthquake) through sample case. Analysis of cases conducted according to Marjorie Gordon's Functional Health Patterns.

Key words: Post traumatic stress disorder, natural disaster, pediatric nursing, Gordon's Functional Health Patterns, case analysis.
\end{abstract}

\section{Fonksiyonel Sağlık Örüntüleri Modelinin Kapsamı ve Önemi} Marjory Gordon, hemşirelik eğitimi ve uygulamalarında önemli katkısı olan bir kuramcıdır. Gordon, hemşirelik bakımının insan gereksinimlerinden doğduğunu vurgulamaktadır. Marjory Gordon ${ }^{1} 1982$ 'de, bireyleri biyopsikososyal yönüyle ele alan bir hemşirelik bakımı modeli geliştirdi. Fonksiyonel Sağlık Örüntüleri (FSÖ) olarak adlandirılan bu model, bireylerin gereksinimlerini; 1) Sağlığın algılanmas1Sağlığın yönetim biçimi, 2) Beslenme şekli ve metabolik durumu, 3) Boşaltım şekli, 4) Aktivite egzersiz şekli, 5) Uyku-istirahat şekli, 6) Bilişsel algılama şekli, Kendini 7) Algılama kavrama şekli, 8) Rol ilişki şekli, 9) Cinsellik ve üreme, 10) Baş etme, stresi tolere etme şekli, 11) İnanç ve değerleri olmak üzere 11 fonksiyonel alanda açıklamaktadır. Bu alanlar, sistematik ve standardize edilmiş bilgi toplama yaklaşımı ve hemşirelik bakış açısı ile bilginin analiz edilmesini sağlamaktadır. Fonksiyonel Sağlık Örüntüleri Modeli; hemşirelik sürecinde, kritik düşünme ve klinik karar verme üzerinde durmaktadır. Gordon'un ${ }^{1,2}$ FSÖ, hastane ve toplum sağlığ alanlarında hemşirelik girişimlerinin düzenlenmesi ve değerlendirilmesi için kullanılmaktadır. $\mathrm{Bu}$ örüntüler hem birbiri ile hem de hastalık durumu ile ilişki içinde olup, birbirine bağımlıdır. Bireylerin bütüncül bakış açısı ile değerlendirilebilmesi nedeniyle FSÖ modelinin, doğal afet nedeniyle post travmatik stres bozukluğu yaşayan çocukların sağlı bakımı gereksinimlerinin belirlenmesi için, uygun olduğu düşünülmüştür.

\section{Doğal Afet ve Post Travmatik Stres Bozukluğu İlişkisi}

Deprem, kasırga, hortum, yangin veya sel gibi bir felaket yetişkinler için olduğu gibi çocuklar için de korkutucudur. Çeşitli faktörler çocuğun afete karşı tepkisini

Geliş Tarihi/Received:20.01.2015/Kabul Tarihi/Accepted:09.07.2015

${ }^{a}$ Doç. Dr. İstanbul Üniversitesi Sağlık Bilimleri Fakültesi,Ebelik Bölümü, email inalsevil@gmail.com

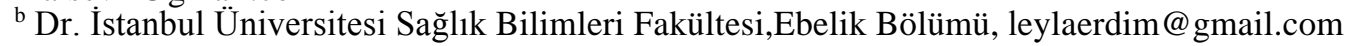


etkiler. Çocuğun tepkisi, afet sırasında ve sonrasında ne kadar yıkım ve/veya ölüm gördüğüyle de ilişkilidir. Eğer bir aile üyesi ya da arkadaş afette ölmüş veya ciddi biçimde yaralanmışsa, çocuğun okulu veya evi ciddi biçimde hasar görmüşse, çocuğun güçlükler yaşayacağı büyük değişiklikler meydana gelecektir ${ }^{3,4}$. Bir felaket sonrasında çocukta PTSB gelişebilir, korkutucu travmatik olayı deneyimlemekten veya tanık olmaktan kaynaklanabilen bazı semptomlar görülebilir. PTSB yaşayan çocuklar genellikle travmatik olayı tekrar tekrar yaşarlar. Küçük çocuklarda travmatik olay bazen kötü rüyalara, kabuslara neden olabilir. Bazen başkalarına veya kendine zarar verme davranışı görülebilir. PTSB nadiren bir travma sırasında ortaya çıkar. Semptomların olaydan kısa bir süre sonra görülebildiği, bozukluğun ise olaydan aylar ya da haftalar sonra ortaya çıkabildiği düşünülmektedir $4,5,6,7$.

Bir afet yaşandıktan sonra hemşire çocuğun davranışlarında meydana gelebilecek aşağıdaki değişikliklerin farkında olmalıdır.

- Okula dönmeyi reddetme ve anne babaya yapışma davranışı, anne babayı bir gölge gibi takip etmek.

- Felaketle ilgili tekrarlayan inatçı korkular (örneğin ebeveynlerden ayrı kalma korkusu).

- Olaydan günler sonra görülen, birkaç günden fazla süren kabus, uyku sırasında çığlık atma gibi uyku sorunları, sürekli altını 1slatma.

- Huzursuzluk ve konsantrasyon kayb1.

- Korkma veya kolayca ürkme.

- Okulda ya da evde çocuk için alışılmışın dışında davranış problemleri.

- Mide ağrısı, baş ağrısı, baş dönmesi gibi fiziksel nedeni bulunamayan fiziksel problemler.

- Aile ve arkadaşlardan uzaklaşma, üzüntü, kayıtsızlık, aktivitede azalma, afetle ilgili olaylarla ilgilenme.

PTSB olan çocuğun bakımında pediatri hemşiresi önemli bir rol oynar. Bir felaketten etkilenen, özelliklede bir kayba, yaralanmaya veya ölüme tanık olan çocuklar için, hemşirelik bakımı PTSB önlemeye ya da azaltmaya yardımcı olabilir ${ }^{5,6,7,8}$.

Öncelikli hedefler; Çocuk ve ailenin güvenliğini sağlamak, çocuğun kendine saygısını arttırmak, duyguları ve hareketleri üzerinde yeniden kontrol kazanmasına yardım etmek, saldırganca davranmak yerine girişken davranmaya cesaretlendirmek, meydana gelen olaylara ve değişikliklere gerçekçi bir uyum sağlamaya yönelik sağlıklı yollar öğrenmesi için çocuk ve aileye yardım etmek gibi konuları içerir.

Beklenen sonuçlar; Çocuğun kendilik algısının gelişmesi/güçlenmesi, çocuğun bireysel reaksiyonlarını ve hislerini kabul etmesi, ifade etmesi ve uygun şekilde ele alması, çocuğun fiziksel yakınmalarının azalması, çocuğun yaşam biçiminde uygun değişiklikler yapması, çocuğun sonraki ihtiyaçlarını karşılamak için plan yapması olarak özetlenebilir.

$\mathrm{Bu}$ makalede doğal afet nedeniyle(deprem) PTSB gelişen çocuk ve ailenin bakım planı bir örnek vaka aracılığıyla Marjory Gordon'un Fonksiyonel Sağlı Örüntüleri Modeline göre veri toplama sürecinden itibaren ele alınarak, oluşturulmuştur. Makalenin hemşirelerin, bir model yardımıyla veri toplama, hemşirelik tanısı koyma, amaç, gösterge ve girişimlerin belirlenmesinde izlenebilecek yolların belirlenmesinde yol gösterici olacağı düşünülmektedir.

Olgu: E.G. 7 yaşında bir kız çocuğudur. 40 gün önce meydana gelen depremde evlerinde ailesiyle birlikte göçük altında kalmıştır. Babasını depremde kaybeden E.G. depremden yaklaşık 2 saat sonra kurtarılmış ve hastanemizin ortopedi servisine sevk edilmiştir. Sağ bacağındaki parçalı kırık nedeniyle iki operasyon geçirmiş, bacağ 1 alçıya alınmıştır. Halen hastanemizin ortopedi servisinde yatmakta olan E.G.'nin annesi, depremden bu yana yaklaşık 40 gündür devam eden uykusuzluk, uykudan sıçrayarak uyanma, kâbus görme, çevreye ilgisinin kaybolması ve iştahsılılı şikâyetleri olduğunu belirtmektedir. E.G.'nin, hemen 
hemen her gün ağladığı gözlenmektedir. Odandan hiç çıkmak istememekte, sırtını dönerek saatlerce hiç kimseyle konuşmadan yatmaktadır. Ayrıca, annesinin kısa süreli bile olsa odadan ayrilmasina izin vermemekte, tuvalete girdiğinde banyo kapısının kapatılmamasinı istemekte, uyurken annesinin elini tutması, gece sşığın kapatılmamas1 konusunda 1srar etmektedir. E.G'de depremden sonra sekonder enürezis geliştiği gözlenmiş, yapılan ürolojik değerlendirmede enürezisin fiziksel bir nedeni olmadığ 1 belirlenmiştir. Psikiyatrik değerlendirmede enürezisin (noktürnal) bir regresyon davranışı olduğuna karar verilmiştir. Ayrıca E.G. Post Travmatik Stres Bozukluğu (PTSB) teşhisi konulmuş, tedavisine Fluoksetin 7 mg 1x1 eklenmiş ve haftada 2 kez psikiyatristle 1 saatlik görüşme planlanmıştır. Halen kırığın tedavisi ve rehabilitasyonu amaciyla servisimizde yatmakta olan E.G'nin Vaka analizi Marjorie Gordon'un Fonksiyonel Sağlık Örüntüleri Modeline göre gerçekleştirilmiştir.

\section{Sağlığın Algılanması ve Sağlık Yönetimi:}

E.G. mevcut sağlığını, "kötü” olarak tanımlamaktadır. Annesi E.G'nin deprem öncesi sağlığını sürdürmeye ve geliştirmeye yönelik yaşına uygun düzeyde sorumluluklar aldığını, pek çok faaliyette bulunduğunu (haftada 2 gün düzenli spor yapma, günlük vücut hijyenini sağlama, diş firçalama, sağlıklı beslenme vb) belirtiyor. E.G. sağlıklı yaşam biçimi davranışlarının, sağlığ üzerindeki etkisi konusunda yaşına uygun bilgi düzeyine sahip. Ancak sağlıklı yaşam biçimi davranışlarını gerçekleştirme konusunda oldukça isteksiz. Banyo yapmak ve dişlerini furçalamak istemiyor. Tedavisinde yer alan ilaç ve veriliş amacı hakkında bilgi sahibi olmasına rağmen ilacı düzenli olarak zamanında alma konusunda isteksiz. E.G'nin herhangi bir alerjik problemi yok. Sağlık güvencesi var ${ }^{9,10}$.

\section{Beslenme Şekli ve Metabolik Durum:}

Doğduktan sonra ilk 6 ay sadece anne sütüyle beslenmiş, 6 . aydan sonra uygun ek gidalarla 15. aya kadar anne sütü almış. Depremden önce, iştahlı ve yaşına uygun yeterli ve dengeli besin alımı var. Depremden sonra ve hastanede yatma sürecinde; besin alımında azalma, iştahsızlık, beslenmeye karşı isteksizlik, sık sik ögün atlama gözlenmiştir. E.G'nin büyüme ve gelişmesi yaşına uygun. Hastaneye yattığında fiziksel ölçümleri; Tart1: 23 kg (50Persantil), Boy: 120 cm (50 persantil), \$̧ndiki fiziksel ölçümleri; Tartı: 21 kg (25. Persantil), Boyu: 120 cm (50. Persantil) olarak belirlendi. Operasyon sonras1 yara iyileşmesi beklendik düzeyde ${ }^{9,10}$.

\section{Boşaltım Şekli:}

Defekasyon normal kıvamda ve siklikta. Sindirim sistemi, üriner sistem ve deri ile ilgili herhangi bir fiziksel sorun yok. Depremden sonra gelișen ve halen devam eden sekonder enürezis (noktürnal) mevcut. Enürezisin fiziksel bir nedeni olmadığı, bir regresyon davranışı olduğu belirlendi ${ }^{8,9}$.

\section{Aktivite ve Egzersiz Şekli:}

E.G. zamanının büyük bir kısmını yatarak ve yatağında televizyon izleyerek geçiriyor. Gün boyunca oldukça pasif ve az hareket ediyor, boş zamanlarını değerlendirmeye yönelik herhangi bir aktiviteye ilgi göstermiyor. Kardiyovasküler sistemini etkileyen bir hastalığı yok ancak bacağındaki alçıdan kaynaklı aktivitelerini karşılamada ve koltuk değneğiyle yürümede zorlandığını, çabuk yorulduğunu ve düşmekten korktuğu için yürümek istemediğini belirtiyor. Mental motor gelişimi yaşına uygun özellikler taşıyor. Göz teması kurma, konuşma ve iletişim kurma konusunda isteksiz ${ }^{9,10}$.

\section{Uyku ve Dinlenme Şekli:}

E.G. zamanının çoğunu yatağında pasif olarak geçirme eğiliminde olduğu için gündüz s1k sik uykuya dalıyor ve kısa aralarla uyuyor. Ancak gece uykuya dalmakta güçlük çektiğini ve bir kez uyandığında tekrar uykuya dalmakta zorlandığını ifade ediyor. Gece uyurken annesinin yanında olmasinı, elini tutmasinı 
ve 1şıkların gece boyu açık kalmasını istiyor. Gündüz yaklaşık 2 saat kısa aralıklarla uyurken, gece ortalama 4 saat uyuyor. Geceleri s1k sık uyandığını, kabuslar gördügünü söylüyor. Annesi, gece ağlayarak uyanmaların ve uyku sırasında sıçramalarının olduğunu belirtiyor ${ }^{9,10}$.

\section{Bilişsel-Algısal:}

E.G.'de herhangi bir duyu kaybı yok. Kendini ifade etme becerisi yaşına uygun düzeyde ancak kendini sözel olarak ifade etme konusunda oldukça isteksiz. E.G. ilköğretim 1. sınıf öğrencisi, okuyabiliyor ve yazabiliyor. Mental ve duyusal fonksiyonlarını etkileyen herhangi bir hastalığ1 yok. Ağrısı olduğunda ağrısını ve nedenini tanımlayabiliyor. Uzun süredir ağrısı olmadığını ifade ediyor ${ }^{9,10}$.

\section{Kendini Algılama/Kavrama Şekli:} E.G. kendini mutsuz olarak algilıyor. Gün içinde sıklıkla kötü bir şeyler olacağı duygusu ve huzursuzluk yaşadığını ifade ediyor. Annesi, E.G.'nin “yeniden deprem olur mu, biz de ölür müyüz" diye sorduğunu belirtiyor. Annesi E.G.'nin bacağındaki kırığın tam olarak iyileşmeyeceği, çirkin görüneceği ya da tekrar koşup oynayamayacağına ilişkin endişeleri olduğunu ifade ediyor. Anne depreme kadar hayatlarında her şey normal ve yolunda giderken depremle her şeyin altüst olduğunu, eşini ve çocuğunu kaybetmenin çok büyük üzüntüsünü yaşadığını belirtiyor $^{9,10}$.

\section{Rol/İlişki Şekli:}

Kendisini, okulda başarılı bir öğrenci olarak görüyor ve arkadaşları tarafindan çok sevilen, çok arkadaşı olan biri olarak tanımlıyor. Deprem öncesi arkadaşları ile sık sık evde ve dișarıda buluşup oynadığını belirtiyor. Şu anda annesi dişında hiç kimseyle diyalog kurmaya yanaşmiyor. Annesinin, arkadaşlarıyla telefon görüşmesi ve hastane ziyareti yapma önerisini kabul etmiyor. Babasıyla ilişkilerinin çok iyi olduğunu annesi, "en çok babasını severdi" şeklinde ifade ediyor. Anne rol ve ilişkilerinde önemli değişiklikler yaşadığını,
"Daha önce bir telefon faturası bile yatırmamıştım, şimdi her şeyle tek başıma ilgilenmek zorundayım" diyerek ifade ediyor. Anne eşiyle mutlu bir beraberlikleri olduğunu, iyi geçindiklerini, eşini çok özlediğini ifade ediyor ${ }^{9,10}$.

\section{Cinsellik:}

E.G. cinsiyetinden hoşnut olduğunu ifade ediyor. Büyüyünce tıpkı annesi gibi bir kızının olmasını istediğini söylüyor. Üreme sistemi ile ilgili herhangi bir hastalık ya da bozukluk belirlenmedi. Yaşına özgü gelişimsel özelliklere sahip ${ }^{9,10}$.

\section{Baş Etme, Stresi Tolere Etme Şekli:}

E.G. stresle baş etmede, içe kapanma (kimse ile konuşmak istemiyor, zamanının çoğunu yatarak geçirme eğiliminde, odadan dişarı çıkmıyor), mantığa bürüme (yemek yememe nedeni olarak yemeklerin güzel olmamasını gösteriyor, regresyon vb. (sekonder enürezis) tepkiler gösteriyor. Duygularını sözle ifade etmediği ve kızgınlığını dışa vurmadığ1 görüldü. E.G.'nin depremle ilgili konuşmaktan kaçındığı gözlendi. E.G. fiziksel olarak dinlenmiş görünmüyor, gözlerinin altı çökük ve yüzü yorgun. E.G.'nin annesi Ayşe Hanım kederli görünüyor. 40 gündür hastanede yattıklarını, bunun kendisini hem ekonomik hem de ruhsal açıdan yorduğunu, kendisini yorgun ve bitkin hissettiğini söylüyor. E.G.'nin bakımına yardımcı herhangi bir kişinin olmadığını belirtiyor. Ayşe Hanım, zaman zaman kendini çok mutsuz ve tükenmiş hissettiğini ancak, kızının başka dayanağ olmadığ1 için "her şeye rağmen kızım için ayakta kalmalıyım" diyerek ifade ediyor. Ablası ile üzüntülerini ve sıkıntılarını paylaştığını, bunun onu biraz rahatlattığını söylüyor. Ablası dişındaki diğer akrabalarının şehir dışında olduğunu, kendisine maddi ya da manevi herhangi bir destekleri olamadığını belirtiyor ${ }^{9,10}$.

\section{1. İnanç ve Değerleri:}

Anne çocuğunun durumunda iyileşme olmasından çok mutlu olduğunu, "Ne yapalım kader, bizden kötü olanlarda var, biz 
hiç olmazsa birbirimize destek olabiliyoruz, ya kimsesi kalmayanlar ne yapsın" diyerek ifade ediyor ${ }^{9,10}$.

\section{NANDA'YA GÖRE HEMŞİRELIK TANILARI}

1) Ebeveyn kaybi ve hastaneye yatmaya sekonder yeme isteğinin azalmasına bağlı beslenmede dengesizlik: Gereksinimden az beslenme

\section{Tanımlayıcı Özellikler}

Kilo kaybı (40 günde $2 \mathrm{~kg}$ ), önerilen günlük miktardan daha az besin alma, öğün atlama (özellikle kahvaltı), iştahsızlık.

\section{Amaçlar}

E.G. günlük olarak metabolik gereksinimleri ve aktivite düzeyine uyumlu yeterlilikte besin alacak.

\section{Göstergeler}

E.G. ve annesinin; iyi beslenmenin önemini açıklaması, günlük alımdaki eksiklikleri tanıması, iştahı arttıracak yöntemleri tanımasi.

\section{Girişimler}

- Diyetisyenle görüşülerek, gerekli ve yeterli günlük kalori gereksinimi tanımlandi.

- Günlük olarak vücut ağırlığı tartıld1, laboratuar sonuçları izlendi.

- E.G. ve annesine yeterli beslenmenin önemi açıklandi.

- Her bir ögünün amaçları E.G. ve annesiyle tartışıld1.

- Anneye besinlerin koku ve tadinı iyileștirmek için baharat kullanması önerildi.

- E.G. yaşıtlarıyla servisin yemek odasında yemeye teşvik edildi.

- Bakım ve tedaviler yemeklerden önce ağrılı ya da hoş olmayan işlemler olmayacak şekilde planland.

- Yemek için hoş, rahat bir ortam sağlandi.

- Bakım planı, yemekten hemen önce bulant1 yaratan kokular ve işlemler yer almayacak şekilde düzenlendi.
- Günde 2 kez dişlerin firçalanması ve sık sık ağzını çalkalanması sağlandı.

- $\mathrm{Az}$ az ve sık sik beslenmesi sağlandi (3 ana, 2 ara öğün).

- İştah arttırıcı önerilerde bulunuldu; (Kisitlama yoksa tuzlu besinler yemek, çok tatlı, ağır yağlı yada kızartılmış besinlerden kaçınmak, açık, berrak, serin içecekler içmek, içecekleri pipetle yavaş yavaş yudumlamak, yağı az, küçük porsiyonlar yemek, az ve sik yemek, yemek kokularından uzak durmak, soğuk yenen besinleri tercih etmek).

2) Yaşanılan travmatik olaylaylara sekonder regresyona bağlı üriner boşaltımda bozulma (sekonder enürezis)

\section{Tanımlayıcı Özellikler}

Enürezis noktürna (40 gündür devam eden haftada en az 3 kez uyurken idrar kaçırma var).

\section{Amaçlar}

Çocuk uyku döngülerinden kuru kalkacaktır.

\section{Göstergeler}

E.G. ve annesinin yatmaya yakın saatlerde sıv1 alınımın azaltılması gibi enürezisi azaltacak faktörleri bildirmesi.

\section{Girişimler}

- Enürezisin doğası anneye açıklandı.

- E.G.'de enürezis noktürnanın gelişme nedeni ve regresyon davranışı ile ilgili anneye bilgi verildi.

- Regresyon davranışına uygun yaklaşım biçimi konusunda anne eğitildi (görmezden gelme, utandırmama vb).

- Anneye, hoşnutsuzluk gösterme, ayıplama ve cezalandırmanın enürezisi durdurmadığı, sadece çocuğu utandırdığ mahcup ettiği ve korkuttuğu anlatıld1.

- Çocuğun işbirliği yapmasını pekiştirmek amaciyla ödüllendirme ve oyun yönteminden yararlanıldı.

3) Alçıya sekonder kas gücünde azalmaya ve aşırı sedanter yaşam şeklinin kondüsyonu bozucu etkisine bağlı aktivite intoleransi. 


\section{Tanımlayıcı Özellikler}

Yürürken güçsüzlük, zayıflık, baş dönmesi, çabuk yorulma. Yürüdükten üç dakika sonra; efor yorgunluğu, solunum hizında $\operatorname{artış}(>24 / d k)$, nabız hızında artış $>95 / d k)$.

\section{Amaçlar}

E.G. aktivite düzeyini ilerletecek. Yatak dışında geçirilen zaman her gün $15 \mathrm{dk}$ arttırılacak. Uyuma saatlerinin dışında yatakta geçirilen zaman kademeli olarak azaltılacak.

\section{Göstergeler}

E.G. ve annesinin; aktivite intoleransinı arttıran faktörleri tanıması, aktivite intoleransını azaltacak yöntemleri tanıması, aktivite sonrası E.G.'nin kan basincının 3 dk içinde normal sınırlara dönmesi.

\section{Girișimler}

- E.G.'nin aktivite tepkisi izlendi.

- Dinlenme halindeyken kan basinc1, solunum ve nabız hızı değerlendirildi (Kan basinci 90/60 mmHg, solunum 22/dk, nabız 88/dk).

- Aktiviteden hemen sonra yaşam bulguları alınd1 (Kan basinc1 85/60 mmHg, Solunum 26/dk Nabiz 104/dk).

- Aktivite sonrası $3 \mathrm{dk}$ dinlendikten sonra, yaşam bulguları tekrar değerlendirildi (Kan basinc1 90/60 mmHg, Solunum 26/dk Nabiz 104/dk).

- Aktivite sonrası (koridorun başından sonuna kadar yürüyüş) dispne, baş dönmesi görülmediği için aktiviteye devam edildi.

- İstirahat halinde nabız hızına dönüş 3 dk'dan uzun sürdügü için aktivite süresi, sıklığ1 ve yoğunluğu azaltıldı.

- Aktivite yavaş yavaş arttırıldı (ilk 2 gün koridorun yarısına kadar 2 kez yürüme, 2 . günden sonra koridorun sonuna kadar yürüme).

- İlk gün, günde $2 \mathrm{kez} 5 \mathrm{dk}$ alçılı bacağa pasif, alçısız bacağa aktif egzersizler uygulandi.
- Sonraki günlerde aktif ve pasif egzersizin süresi ve sıklığı kademeli olarak arttırıldı (bir haftanın sonunda $2 \times 15 \mathrm{dk} /$ ün).

- E.G.'nin dinlenme periyotları günlük programına göre planlandı.

- Dinlenme periyotları arasina aktif oyun saatleri konularak sedanter geçen süre azaltıld1.

- Gündüz uyku miktarını azaltmak için dinlenme zamanlarını yatakta değil de odadaki kanepede, yar1 oturur pozüsyonda uzanarak geçirmesi sağlandi.

- Aktiviteyi arttırmayı cesaretlendirmek için mobilite durumunu geliştirebileceğine inanıldığı E.G.'ye açıklandı, ilerlemeleri övüldü.

- Kendi aktivite programının oluşturulmasına aktif katılmaya teşvik edildi.

- Aktiviteyi arttırmaya teşvik etmek için ödüllendirildi (koridorun sonuna kadar 2 kez yürüdüğünde kendisine hikaye okunacağı söylendi).

- Aktivite düzeyi, süresi ve sıklığı kademeli olarak arttırılarak E.G.'nin aktivite toleransı arttırıldı (günde $3 \mathrm{kez}$ yataktan çıkararak yatak dışında geçirilen zaman her gün 15 $\mathrm{dk}$ arttırildi).

- E.G.'nin aktivite arttırma hızını değerlendirmesine izin verildi.

- Yürürken ayakkabı giymeye teşvik edildi.

- Gün boyunca aralıklarla ve yemekten sonra 1 saat dinlenmesi sağland.

- Yaşına uygun oyunlar ve yorucu olmayan aktiviteler sağland;; Öyküler anlatmak ve yazmak, bebekle oynamak, resim yapmak, kağıt oyunları oynamak, evcilik, kitap okuma, servisteki yaşıtlarıyla uygun oyunlar vb).

4) Gündüzleri fazla uyumaya sekonder sirkadyan ritmin değişmesine bağlı uyku örüntüsünde rahatsızlık.

\section{Tanımlayıcı Özellikler}

Uykuya dalmakta ve uyumada güçlük, ece s1k s1k uyanma ve yeniden uykuya dalmakta zorlanma, yorgun uyanma, gün boyunca kendini yorgun hissetme ve uyuklama, gece 
boyunca 1ş1kların açık kalmasını isteme, gece sik sik ağlayarak ya da kabuslarla uyanma.

\section{Amaçlar}

E.G. ve annesi dinlenme ve aktivite arasında bir denge olduğunu bildirecek. Uyuma saatlerinin dışında yatakta geçirilen zamanın kademeli olarak azaldığını bildirecek.

\section{Göstergeler}

E.G. ve annesinin; uyumayı güçleştiren ve engelleyen faktörleri tanımlaması, uyku getiren teknikleri tanımlaması.

\section{Girişimler}

- Uyku saatlerinde gürültü ve sesleri azaltacak önlemler alınd.

- Takip, tedavi ve bakımlar mümkün olduğunca uyku düzenini aksatmayacak şekilde sürdürüldü.

- Gece yatma saatine yakin sivi alımı kısitlandı ve yatmadan önce idrar yapması sağland1.

- Çocukla birlikte gündüzler için uygun aktivite programı oluşturuldu ( yürüyüş, fizik tedavi, aktif pasif egzersizler vb).

- Gündüz uykusu 1 saat ile sinırlandı.

- E.G.'nin alışageldiği uyku öncesi rutinleri, zamanı ve kuralları (diş firçalama, yatmadan önce masal okuma ve bebeğine sarılma) sürdürüldü.

- Kafeinli içecek alımı kısıtlandı.

- Yatma zamanına yakın (3 saat içinde) egzersiz yapmaması sağland.

- Uyku ve dinlenme rahatsızlığının nedenleri ve bunu önleme yolları E.G. ve annesine açıklandı.

- Düzenli yatma ve yataktan kalkma zamanlarına uyması sağlandı.

- Uyumaya hazırlık için gevşemeyi sağlayan bir rutin (sıcak banyo, hafif bir müzik dinleme) sağlandı.

- Yatak odasının hafif serin olması sağland1.

- Kabus gördüğünde, bunun hakkında konuşmaya cesaretlendirildi.

- E.G.'nin karanlık üzerinde kontrol sağlaması için bir gece lambası yakılması sağland1.
- Bütün gece annesinin yakınında olacağ1 açıkland1.

5) Depremde göçük altında kalmaya ve ebeveynin ölümüne sekonder anksiyete.

\section{Tanımlayıcı Özellikler}

Kötü bir şey olacağı duygusu yaşama, uykuya dalmakta güçlük, gece sik sik kabuslarla uyanma, iştahsızlık, günlük olağan ses ve hareketlerden aşırı ürkme (kapının çarpması, telefon çalma, yemek arabasının sesi vb).

\section{Amaçlar}

E.G. psikolojik ve fizyolojik rahatta artma ifade edecektir.

\section{Göstergeler}

E.G.'nin kendi anksiyetesini ve baş etme örüntülerini tanımlaması ve baş etme mekanizmalarını kullanması.

\section{Girişimler}

- E.G.'nin anksiyete düzeyi değerlendirildi.

- Rahatlığ1 ve güvenliği sağland.

- Annesinin sürekli yanında olmas1 sağland.

- Tüm insanların zaman zaman anksiyete hissedebileceği açıklandı.

- E.G. ile konuşurken kısa, basit cümlelerle sakin ve yavaş konuşmaya dikkat edildi.

- Empatik bir yaklaşım kullanıldı (dokunma, ağlamaya izin verme, konuşma vb).

- Fazla uyaranlar uzaklaştırılırdı, daha sessiz bir oda sağlandi.

- Anksiyeteli diğer kişilerle ilişki sinirlandirıldi.

- Anksiyete öğrenmeyi engellemeyecek kadar azaldığında, öğrenme ve problem çözmeyi başlatmak için E.G'in anksiyetesini tanımasına yardım edildi.

- Baş etme mekanizmalarının etkili olup olmadığı değerlendirildi.

- Stresli durumlar kaçınılmaz olduğunda kullanılmak üzere anksiyeteyi azaltma teknikleri öğretildi (Uzağa bakma, 
solunumun kontrolü, yavaş düşünme, egzersiz vb.)

- Gerilimi azaltan aktiviteler belirlendi (oyunlar, müzik dinleme, gevşeme egzersizi, hayal etme vb).

- Gerilimi azaltacak aktivitelerden uygun olanlar uygulandi.

- Psikiyatrik değerlendirme için yönlendirildi.

- Basit yaşa uygun terimler kullanarak olaylar açıklandi.

- Çocuğun alışık olduğu oyuncakları ve eşyaları bulundurmasına izin verildi (evdeki yastıği, bebeği).

- Güven verici bir ilişki kuruldu.

- Annenin çocuğun yanından ayrılması en aza indirildi.

- Duygularinı ifade etmeye cesaretlendirildi.

- Servisin oyun odasinda aktif oyun oynayabileceği fursatlar sağlandi.

- Rahatlatıcı önlemler alındı.

- Annenin bakıma aktif katılımı sağlandı.

- Anne, E.G.'nin anksiyete nedenleri ve yapabilecekleri konusunda bilgilendirildi.

- Annenin çocukla birlikteyken anksiyetesini yönetmesine yardım edildi.

- İlacını düzenli olarak alması sağlandı.

- Kullandığı ilacın etkileri, yan etkileri açısından gözlendi.

6) Ebeveyn ölümüne sekonder duygusal destek kaynağının ve yaşam şeklinin değişimine bağlı acı çekme.

\section{Tanımlayıcı Özellikler}

Ebeveynin ölümünden duyulan üzüntünün ifade edilmesi, keder, özleyen arayan davranışlar (babasının saatini takıyor).

\section{Amaçlar}

Yas tutma sürecini ilerletmek ve iyileştirmek. Çocuğun acısını kederini ifade etmesini sağlamak.

\section{Göstergeler}

E.G. ölüm ve kaybın anlamını tanımlaması, kederini diğer önemli kişilerle (anne, hemşire vb) paylaşmasi.

\section{Girişimler}

- E.G. ile güven duyacağı bir ilişki sağland1.

- E.G. ve annesinin yas tepkileri desteklendi.

- Anneye acı çekme yas tepkileri açıklandı (şok ve inanmama, farkındalık geliştirme, eski haline dönme durumunu yeniden düzenleme, somatik belirtiler).

- Kayıpla ilgili olarak yaşananlar değerlendirildi.

- E.G. ve annesinin güçlü yönleri vurgulandı (annesi ve kendisi sağllklı, herhangi bir majör sağlik sorunu yok).

- Kendi duygularını değerlendirmeleri ve birbirlerini desteklemeleri için E.G ve annesi cesaretlendirildi.

- E.G. acı çekme duygularını annesiyle paylaşması için cesaretlendirildi.

- Ac1 çekme sürecinin başarıyla tamamlanmasinı engelleyebilecek faktörler izlendi.

- Ölü kişiye aşırı bağımlılık olup olmadığ değerlendirildi.

- E.G. ileri destek için psikiyatriste yönlendirildi.

7) Depreme sekonder yaşanılan kayıplara ve yoğun anksiyeteye bağlı post-travma tepkisi.

\section{Tanımlayıcı Özellikler}

Travmatik olayın bilişsel, duygusal olarak, ya da duyusal-motor aktivitelerle tanınabilen şekilde yeniden yaşanması (geriye dönüşler, istemsiz zorlayıcı düşünceler), tekrarlayan rüyalar, kabuslar, sikıntı-keder, acı veren duygu, hüzün, olayın tekrarlayacağ 1 korkusu, ölüm korkusu, aşırı tetikte olma ya da sakınma tepkileri, önemli aktivitelere ilgide azalma, travmaya ilişkin fobilerin gelişmesi, travmayı anımsatacak aktivite yada durumlardan kaçınma, uyku rahatsızlıkları.

\section{Amaçlar}

E.G. deneyimini anlamlı bir bütün olarak özümseyecek ve yaşam amaçları oluşturacak 
şekilde kendi yaşamına devam etmeye yönelecek.

\section{Göstergeler}

Uyuşukluk, ilgisizlik belirtilerinde azalma olması, ya da travmayı anımsayarak yeniden yaşama durumunda bir azalma olduğunu bildirmesi. Travmatik olayın gerçekliğini kabul etmesi ve korku, suçluluk gibi duygularını ifade ederek, deneyim hakkında konuşarak, travma ile yüzleşip başa çıkmaya başlaması. Destekleyici kişi/kaynakları tanıması ve bağlantı kurması.

\section{Girişimler}

- Sessiz bir odada çocuk ile birlikte neler olup bittiği hakkında konuşuldu.

- Burada güvende olduğu açıklandi.

- Yaşadıklarını yeniden yaşama durumu ve donukluk belirtilerini azaltmak için, çocuğa yardım edildi. Kontrolünü yeniden kazanabileceği terapötik ve güvenli bir ortam sağlandı.

- E.G. ile birlikte kalınarak yüksek anksiyete nöbeti sirasında destek olundu.

- E.G. ve annesine bu tür travmatik olaylardan sonra bu tür duyguların ve belirtilerin sıklıkla yaşanabileceği açıklandı.

- Travmatik olayın, gerçekliğini görmesi, deneyim hakkında konuşarak, korku, öfke, suçluluk gibi duyguları ifade ederek travma ile başa çıkmaya başlamasına yardım edildi.

- Eski aktivitelerine yeniden devam etmesi ve bazı yeni aktivitelere başlaması için cesaretlendirilir.

- Annenin kızının niçin böyle etkilendiğini anlamasina yardım edildi.

- Duygularını açığa vurması için cesaretlendirildi.

- Anneye travmayı yeniden anımsama, ağlama nöbetleri, sakınmacı davranışlar, abartılmış ürkme refleksinin nedenleri hakkında bilgi verildi.

- Çocuğun yaş ve gelişimsel özelliklerine göre deneyimi nasıl anladığ 1 ve bütünleştirdiği değerlendirildi.
- Oyun terapisi seansi gibi güvenli ve destekleyici bir ortamda deneyimi tanımlamasına ve duygularını ifade etmesine yardım edildi.

- Anlayabileceği şekilde açıklamalar yapıldı, doğru ve tam bilgi sağlandı.

- E.G.'nin gereksinimlerine ilişkin annenin anlayışını geliştirmek için danışmanlık sağland.

8) Ekonomik olanakların yetersizliğine, desteğin olmamasına ve dinlendirici olanakların yetersizliğine bağlı bakım verici rolünde zorlanma.

\section{Tanımlayıcı Özellikler}

Annenin zamanının ve fiziksel enerjisinin yetmediğini bildirmesi, gerekli bakım aktivitelerini yerine getirmede güçlük, kendinin bakım sağlama yeteneğinin ve kızının sağlı̆̆ının gelecekte ne olacağ 1 konusunda endişe yaşaması.

Kendisi hastalanırsa ya da başına bir şey gelirse kızının ne olacağı konusunda korku yaşaması, moral bozukluğu, keder, üzüntü.

\section{Amaçlar}

Bakım verici zorlanma durumunu azaltacak bir plan bildirecek.

\section{Göstergeler}

Bakım verici rolüne ilişkin hayal kırıklıklarının paylaşılması, en az bir destek kaynağının tanımlanması, anneye yardım ve destek için haftalık bir plan oluşturulması.

\section{Girişimler}

- Neden olan ya da arttıran faktörler değerlendirildi. (Durumu kötü olumsuz olarak algilama, yardım istemede yetersizlik ya da çekinme, kaynakların yetersiz kalması, boş zaman yetersizliği.

- Annenin durumla ilgili yorumları değerlendirildi, periyodik olarak yeniden değerlendirme yapıld1.

- Anneye söylenen bilginin ne olduğu, beklentilerin gerçekçi olup olmadığ 1 değerlendirildi. 
- Hangi aktivitelerde yardım istediğini tanımasina yardım edildi; (E.G'nin gereksinimleri, hijyen, dinlenme).

- E.G.'nin bakımını haftada 2 kez 1 saat Ayşe hanımın ablasının üstlenmesi ve Ayşe hanımın dinlenmesi sağlandı.

- Ayşe hanıma empati gösterilerek yeterlilik duygusu sağlamaya çalışıldı.

- Mevcut programin ve sorumluluklarin Fiziksel sağlik, emosyonel durum, ilişkiler üzerine etkileri tartışıldı.

- Ayşe hanımın ablasıyla aşağıdaki konular tartışıld1; (Anne için durumun sıkıntı verici olduğunu kabul ve takdir etmenin, bunu ifade etmenin önemi, öğüt vermeden dinlemenin yararları, duygusal ve takdir edici desteğin yararları, düzenli olarak telefon etme ve ziyaretlerin önemi, E.G.'nin bakımı konusunda haftada 2 gün 1'er saat desteklemeye teşvik edildi, Ayşe hanıma hoş vakit geçirmesi için “ izin vermesi” gerektiği vurgulandı, anneye sana nasıl yardım edebilirim sorusuna cevap verme firsatları sağlamanın gerekliliği açıklandı).

- Olası tüm gönüllü yardım kaynakları tanımlandı (abla, komşular, toplumsal gruplar vb.)

Sonuç olarak; deprem nedeniyle çocukta yaşanan PTSB, hemşirenin sistematik olarak ele alması gereken bir durumdur. Verilerin toplanmasında Gordon'un FSÖ modeli verilerin sistematik olarak elde edilmesinde yararlı olmaktadır. Bu makale, hemşirelere PTSB yaşayan çocukta veri toplama süreci, olası hemşirelik tanıları ve girişimleri açısından yol göstermeyi amaçlamaktadır.

\section{Kaynaklar}

1. Gordon M. Functional health paterns, nursing diagnosis process and aplication.

New York: Mc Graw-Hill Book Comp; 1982.

2. Bradley PJ. Family caregiver assessment. Essential for effective home health care. J Gerontol Nurs 2003;29:2936.

3. Aptekar L, Boore J. Crisis Management,Vol:III, The Emotional
Effects of Disaster on Children: A Review of the Literature, Ed: A Boin, p:340. SAGE Publications Ltd, Losangeles. 2008.

4. Lonigan CJ, Shannon MP, Taylor C. et al. Children exposed to disaster: II. Risk factors the development of posttraumatic symptomatology. J Am Acad Child Adolesc Pscyhiatry, 1994;33:94-105.

5. Alyanak B, Ekşi A, Toparlak D ve ark. Depremden Sonraki 2-6 Aylık Sürede Travma Sonrası Stres Bozukluğunun Ergenlerde Araştırılması. Çocuk ve Gençlik Ruh Sağlığı Dergisi, 2000;7(2): 71-80.

6. Berkem M, Bildik T. İzmit Depreminde Hospitalize Edilen Depremzede Çocuk ve Ergenlerin Klinik Özellikleri, Anadolu Psikiyatri Dergisi 2001;2(3):133-140.

7. Alparslan S, Koçkar Aİ, Şenol S, Maral I. Marmara Depremini Yaşayan Çocuk ve Gençlerde Ruhsal Bozukluk ve Kaygı Düzeyi. Çocuk ve Gençlik Ruh Sağlığ 1 Dergisi 1999; 6(3):135-142.

8. Carrion VG, Weems CF, Ray $R$ et al.

Toward An Empirical Definition Of Pediatric PTSD. The Phenomenology of PTSD Symptoms in Youth. J Am Acad Child Adolesc Psychiatry 2002;41(2):166-173.

9. Birol L. Hemşirelik Süreci, 8. baskı, Etki Matbaacılık, İzmir. 2007.

10. Carpenito-Moyet LJ. Handbook of Nursing diagnosis, Translate: F Erdemir, Nobel Tıp Kitabevleri, İstanbul 2005. 